\title{
НАВЧАННЯ ІНОЗЕМНИХ СТУДЕНТІВ-ФІЛОЛОГІВ ЧИТАННЯ АНГЛОМОВНОГО ПОЕТИЧНОГО ТВОРУ: ОСОБЛИВОСТІ РОБОТИ ВИКЛАДАЧА
}

\author{
Сем'ян Н. В. \\ кандидат педагогічних наук, \\ асистент кафедри методики викладання української та іноземних мов і літератур \\ Інститут філології \\ Київького начіонального університету імені Тараса Шевченка \\ вул. Володимирська, 64/13, Київ, Україна \\ orcid.org/0000-0001-7148-4805 \\ semian.nv@gmail.com
}

\begin{abstract}
Ключові слова: поетичний текст, функції викладача, іноземні студенти, емпатія, методичні завдання, специифіка роботи.
\end{abstract}

Метою статті є детальний огляд проблеми навчання іноземних студентів читання англомовного поетичного твору. У статті запропоноване викладення власного бачення автора щодо методологічної основи використання англомовного поетичного твору як засобу навчання та доведено, що сам художній фундамент процесу навчання повинен бути педагогічно обгрунтований, розроблений до дрібниць і вивірений на практиці. Автором з'ясовано, що подана методика стимулює комунікативні навички і вміння студентів, підвищує мотивацію до навчання, розвиває уяву та креативне мислення, позитивно впливає на взаємодію між студентами під час заняття. 3 огляду на обмежене використання художніх поетичних творів у процесі навчання іноземних громадян іноземної мови, якісний аналіз довів ефективність такої методики 3 урахуванням особливостей роботи викладача в іноземній аудиторії. У дослідженні висвітлюються елементи стратегій та підходи до навчання читання поетичного твору, послідовно надаються рекомендації щодо етапів роботи 3 поетичним твором, також автор пропонує до уваги власні приклади завдань. Разом із вищезазначеним у статті має місце аналіз особливостей роботи викладача з іноземними студентами. Автор виділяє та детально характеризує поведінкові функції викладача, серед яких - функція емоційної підтримки, дослідницька, фасилітаторська та експертна функції. Негативні стереотипи та етноцентричні погляди відіграють важливу роль у адаптації до нової культури та формуванні взаємин між іноземними студентами, отже, на думку автора, окрім навчальних функцій, викладачеві в іноземній аудиторії необхідно оволодіти вмінням працювати з емоційними проявами як з особливим змістом. Компонентний склад зазначеного вміння детально представлений у дослідженні. Автор наполягає на думці, що викладач повинен контролювати емоційний та психологічний стан студентів, виявляти до них підтримку, повагу та емпатію, водночас розмова в аудиторії має носити форму вільного діалогу. Ця стаття доводить, що представлена розробка методичної концепції навчання іноземних студентів англомовного поетичного твору сприяє підвищенню рівня володіння іноземною мовою, формує літературне і мовне почуття у студентів. До того ж виокремлена специфіка роботи викладача допоможе у досягненні вирішення тих методичних завдань, які стоять перед сучасним педагогом англійської мови в іноземній аудиторії. 


\title{
ENGLISH POETRY AS A TOOL OF TEACHING READING TO INTERNATIONAL STUDENTS MAJORING IN PHILOLOGY: SPECIFICITY OF TEACHING
}

\author{
Semian N. V. \\ Candidate of Pedagogical Sciences, \\ Assistant Professor at the Department of Teaching Methodology of Ukrainian and Foreign \\ Languages and Literatures \\ Institute of Philology \\ of Taras Shevchenko National University of Kyiv \\ Volodymyrska str., 64/13, Kyiv, Ukraine \\ orcid.org/0000-0001-7148-4805 \\ semian.nv@gmail.com
}

Key words: poetry-teaching framework, international students, teacher's functions, methodological tasks, specificity of teaching.
The purpose of this paper is to present a broader analytical insight to the English poetry teaching to international students which is considered to create language awareness, promote motivation, creativity, develop imagination and self-expression along with multi-skill development and interaction among learners. As a reaction to often-underestimated value of including literature in the language class, this article proposes a poetry-teaching framework for language practitioners to bridge the gap between literature and language teaching methodology. The paper explores and highlights some of the strategies used to read poetry through different approaches, which remains in the focus of modern scientific research. Step-by-step procedure followed in the framework aimed at helping teachers incorporate poetry into language teaching, while at the same time offering various materials and activities to be used in the teaching practice. Qualitative analyses revealed that poetry can have a place in language teaching by using a systematic and guided framework tailored to the features of a language classroom. The emphasis is placed on the detailed characterization of specificity of teaching international students, describes approaches and gives clear characteristics to psychological aspects in a lesson. The author defines psychological functions of a teacher - they are emotional support and expert functions, as well as investigative and facilitative functions. Negative stereotypes and ethnocentric views refer to international students' perception of each other, thus it is a function of a teacher to help students get accustomed. And language refers to students' ability to express themselves in writing and speaking, and to articulate their ideas and thoughts in class. More specifically, a teacher should take a leading position in a group to provide guidance on a studying process. This research suggests that poetry can become part of language teacher education. In this regard, this article proposes instructions for teachers and teacher educators for the implementation of poetry in language teaching practice, in a class with international students particularly.
Постановка проблеми. Актуальність такої проблеми зумовлена значними змінами, що відбулись в останні десятиліття в методології і практиці навчання іноземних мов: на основі відомої концепції про нерозривний зв'язок між мовою і культурою у міжнародному масштабі підтверджена необхідність поєднання навчання мови і відповідних культурологічних реалій; зростаючим інтересом лінгвістики до текстів 3 герменевтичним потенціалом. Поетичний текст $\epsilon$ надзвичайно насиченим в інформаційному відношенні художнім твором. На думку Ю. Лотмана, «поетична мова $є$ структурою високого рівня складності», яка «дозволяє передати такий об'єм інформації, який $є$ абсолютно недоступним для передачі засобами елементарної власне мовної структури» [6, с. 19]. Робота 3 автентичним художнім поетичним твором завжди посідала важливе місце у сучасній лінгвістиці, проте саме навчально-естетичний потенціал таких творів почав привертати увагу вчених лише останніми роками. 
Аналіз спеціальної літератури показує, що навчанню читання автентичного твору присвятили свої праці такі вчені, як Н. Шанський, І. Гальперін, О. Бирюк, Ю. Дегтярьова, І. Литвиненко, Н. Осадча, Л. Рудакова, О. Снєгова, Є. Пассов та інші. У іноземних студентів-філологів поетичний текст англійською мовою викликає насамперед професійний інтерес 3 точки зору розвитку комунікативної компетентності (зокрема, лінгвосоціокультурної), позаяк сприйняття, зумовлене всією поетичною будовою, спричиняе вирішальний вплив на зародження змістової домінанти поетичного твору $[5 ; 6$, с. 20]. Вилучення інформації поетичного твору зводиться не лише до розуміння самого тексту, але й розвитку емоційної сфери студентів-філологів, вміння сприймати різні конотації слова, розуміти імпліцитне значення окремих елементів твору та його загальної символіки.

Проведене дослідження дозволило з'ясувати, що проблема навчання іноземних студентів читання поетичних творів залишається відкритою, водночас специфіка роботи викладачів в іноземній аудиторії також потребує подальшого вивчення.

Мета статті. Мета цього дослідження полягає в розробці методичної концепції навчання англомовної поезії, орієнтованої на комплексне формування в іноземних студентів-філологів навичок і вмінь роботи з поетичним твором на основі філологічного аналізу в умовах відсутності мовного середовища; у підвищенні рівня літературного і мовного відчуття в іноземних студентів; у виокремленні специфіки роботи викладача та досягненні вирішення тих методичних завдань, які стоять перед сучасними педагогами англійської мови в іноземній аудиторії.

Виклад основного матеріалу дослідження. Завдання вивчення літератури в процесі навчання іноземної мови складні і багатогранні. Прямо чи опосередковано вони пов'язані 3 проблемами залучення в педагогічний процес етичного і естетичного начала, маючи вплив на студентів з позиції послідовного розвитку інтелекту, інтелігентності та інших суспільно і особистісно значущих рис, які $є$ необхідними в нашу технократичну епоху.

Зазначена мета значно розширює перелік функцій, які виконує література як навчальний засіб, бо якість художності навчального процесу та навчально-методичного комплексу стає тим фундаментом, на якому має будуватися вся педагогічна система навчання іноземної мови. Проте, аби успішно витримати таке велике дидактичне навантаження, сам художній фундамент процесу навчання повинен бути педагогічно обгрунтований, розроблений до дрібниць і вивірений на практиці [1, с. 44].
У межах цього дослідження ми спробуємо розглянути цей фундамент у процесі навчання англійської мови в іноземній аудиторії.

По-перше, ми виходимо 3 того, що людська сутність тяжіє до лірики, адже ми $з$ дитинства знайомимось 3 навколишнім світом через вірші, які завдяки своїй мелодійності довго зберігаються в нашій пам'яті. Тому поезія може і повинна розглядатися як найефективніший засіб, за допомогою якого у студентів одночасно створюється почуття мови і знімається мовний бар'єр, особливо в аудиторії без мовного середовища [4, с. 9]. По-друге, така проблематика нас цікавить безпосередньо як викладачів. Цілі навчання, особливості системи мови і умов мовного середовища, відмінні риси самих іноземних студентів - все це неможливо не враховувати під час розробки методичних прийомів для викладацької роботи над поетичним твором, що виявляється непростим завданням, оскільки методика навчання поезії народу-носія виучуваної мови досі залишається малодослідженою сферою.

Методології навчання літератури, читання художнього тексту, аналізу художніх творів були присвячені роботи багатьох учених, таких як Н. Бориско, Т. Бондаренко, Т. Вдовіна, С. Воркачев, М. Дука, В. Черниш та інші, однак вони мають загальний характер. Це важливо, але не досить для викладання «вищої форми існування мови» іноземним студентам у практичному процесі.

Сучасна методика викладання англійської мови як іноземної визнає за літературою особливу роль у процесі навчання. Оскільки література - це вид словесного мистецтва, то завдання викладача англійської мови в іншомовній аудиторії - насамперед шляхом детального аналізу самої словесної тканини літературного твору розкрити його багатий зміст і художню довершеність, показати поетичний твір як поєднання чарівних звуків, почуттів і думок [2, с. 11]. Найголовніше завдання у навчанні читання віршованих творів в іноземній аудиторії - навчити розуміти смисл слова, вдосконалювати культуру мовлення, виховати бережливе ставлення до слова і справжню жагу до читання.

Відомо, що головна складність полягає не стільки в оволодінні граматикою, фонетикою, лексикою чи окремими мовними одиницями, скільки в оволодінні співставленням слів, в умінні відчути потенційні можливості слова. Труднощі сприйняття для іноземних студентів з'являються під час занурення в інший мовний простір під час розуміння мовної логіки. Навчання іноземних студентів англомовного поетичного твору потребує якісно іншого підходу до організації процесу навчання. Ретельна, розсудлива робота 3 поетичним текстом в іншомовній аудиторії повинна 
проходити в інтерактивному режимі. Навчальні ситуації повинні будуватися на основі інтегрованого вивчення літератури, мови, історії і культури i бути націленими на формування комунікативно-мовленнєвої, лінгвостилістичної, літературознавчої, лінгвокультурологічної компетентностей іноземних студентів.

Насамперед необхідно чітко структурувати розподіл мовленнєвої діяльності іноземців-філологів. Зазвичай процес засвоєння навчального матеріалу розподіляється на рівні сприйняття. На першому рівні сприйняття досягається основне у змісті прочитаного. На другому визначається не лише загальна, але й додаткова інформація, встановлюються нові смислові зв'язки. На третьому оцінюється не лише зміст, але і його мовне вираження. На четвертому, вищому рівні, відбувається осмислення ідеї художнього твору [10].

Далі наводимо приклади завдань.

Завдання 1: You are going to read a poem about Britain as it was several decades of years ago. What was life like in 1980's Britain? What circumstances gave rise to the poem? Does the poem spring from an identifiable historical moment? Does the poem speak from any specific culture?

Завдання на розвиток умінь визначати інтеркультурні відмінності у способах подачі інформації в поетичному творі.

Завдання 2: Read the poem. Look at the highlighted words and find out about the meaning which they denote.

\section{Through the 80s}

A time for many a part-time passion, like

the discarded skin of Esprit jeans and low-hip waistline

baring pierced navel with flavor of a chase on the run...

would he dare confess real love as the world tolled for Lady Diana and Charles?

You with me... mom to sun, fire to burn our eyes... I swing on an illusion and steal the time away, rustling along a Mustang's back seat, while some 8-CD tract pleads, "Do you think I'm sexy", dipping in steams of instant affection.

How deep-cheeked your thrills

like Indiana Jones, knocking me

off-balance; and I, a fool ignoring the pain

that you may never Stand By Me, never in blinks of thousand stars, a recycled tune melting in the sand now you are just ozone's hole...

I wrap the scenes along Route 25,

As bittersweet time passes by. Alone.

by Nette Onclaud (2009).

Завдання 3: What circumstances gave rise to the poem? Does the poem spring from an identifiable historical moment? Does the poem speak from any specific culture? What do you know about the life of your native country in 1980s? How much have the times changed?

Завдання на розвиток умінь визначати інтеркультурні відмінності у способах подачі інформаиіiї в поетичному творі.

Завдання 4: Write a one-page critical self-analysis paper about reflecting your understanding of the poem, according to the following plan:

- what I understood best;

- what fragments and semantic meanings I did not understand (or partly understood);

- how the language of the poem supports the overall effect and meaning;

- the reasons that prevented me from understanding the content and meaning of the poem;

- to reach a deeper and fuller understanding I need...;

- my view does not correspond to the majority because....

Завдання на формування рефлексії (самооцінки глибини та повноти розуміння інформації поетичного твору).

На наш погляд, важливо також проводити роботу з розвитку уяви студентів, застосовуючи різноманітні методи. В різних видах мистецтва образ передається по-різному: в літературі - через слово, а в живописі - через зображення. Одним 3 ефективних способів розвитку образного мислення студентів $є$ ілюстративні матеріали, причому це можуть бути як авторські роботи, так і картини майстрів живопису. Наприклад, можна запропонувати в іншомовній аудиторії самостійно виразити на папері образ дощу. Або підібрати до поетичного твору ілюстрацію про дощ. У роботі з розвитку уяви іноземців-філологів бажано використовувати тексти пейзажної лірики, уникаючи складних метафор. За допомогою малюнків студенти-іноземці зображують слова. Перетворення літературних творів на мову фарб відкриває можливості для порівняння, змушує студентів уважно вникнути в словесний текст, пильно розгледіти всі його особливості. Предметна сутність живопису дає матеріал як для формування мовленнєвих навичок, так і для активізації пасивного словника [10, с. 11].

Під час опису і тлумачення ілюстрації художника студенти концентрують увагу на тому, що зображено і наскільки це фактично точно відповідає літературному тексту. Індивідуальні спостереження за тим, чому саме так зображені герої, події, предмети, спонукають студентів до критичного мислення - важливого кроку у формуванні навичок комунікативної компетентності. Фокусування уваги на художніх образах готує студентів до сприйняття свідчень художніх зображень, до головного i найскладнішого розуміння метафоричного мислення. 
Здійснивши аналіз словесно-образної тканини поетичного твору засобом співставлення зорового образу і тексту, студенти доходять до основної мети - розуміння глибинного смислу твору [6]. Використання різних прийомів роботи 3 англомовним поетичним твором збагачує і поглиблюе розуміння іноземцями-філологами художнього тексту, а також посилює естетичну насолоду від художнього твору, викликає інтерес до англомовної літератури загалом.

Під час викладання матеріалу іноземній аудиторії проблемою також $є$ те, що низка викладачів орієнтуються під час проведення занять 3 читання і аналізу англомовного поетичного тексту на виключно наукові розробки у сфері лінгвістики, лінгвостилістики, не враховуючи при цьому навчальний характер роботи з текстом. Заняття проводяться за визначеним уже знайомим шаблоном, результатом чого $є$ неадекватність цілей, прийомів і засобів аналізу та інтерпретації літературного твору, що своєю чергою не активізує, а сповільнює і обтяжує процес навчання.

Викладач іноземної мови у ВНЗ, який працює 3 іноземними студентами, дещо відрізняється від своїх колег з інших кафедр, адже тут уже починають проявлятися певні тенденції, пов'язані 3 посиленням гуманістичного складника у викладанні цієї навчальної дисципліни. Методика навчального процесу, міжкультурне порозуміння й вирішення конфліктів має базуватись на гуманістичному підході, в якому свобода, гідність і відповідальність є основними цінностями, а метою є формування цілісного студента (людини) [3]. Отже, специфіка викладання такої дисципліни як навчального предмета в іноземній аудиторії ставить до педагога більш високі вимоги. Це пов'язане 3 посиленням уваги до реалізації таких функцій вчителя, як функція емоиійної підтримки, дослідниџька, фасилітаторська та експертна функиї [1, с. 4].

Виконання викладачем функції емоційної підтримки передбачає, що він не лише володіє знаннями і досвідом їх передачі, але й умінням брати участь у житті інших людей, не порушуючи їхню автономію, не зазіхаючи на їхній життєвий простір. Зокрема, йдеться про те, що викладач починає центруватися на студентові і на тому, що є значимим для самого студента.

Під центрацією викладача на студентові мається на увазі не просто спрямованість, а зацікавленість, занепокоєність інтересами студента-іноземця, своєрідна вибіркова психологічна зверненість, «обернутість» до нього і, як наслідок, таке ж вибіркове служіння його інтересам [8]. Орієнтація у навчанні на особистісно значущі для студента-іноземця завдання вимагає від викладача готовності поводитись терапевтично, розуміючи, що спілкування зі студентом $є$ насамперед інтенсивним обміном емоційними станами.

Для роботи в руслі особистісного росту викладачеві в іноземній аудиторії необхідно оволодіти вмінням працювати 3 емоційними проявами (своїми і студентів) як 3 особливим змістом. Структуру цього вміння становлять такі компоненти:

- емпатія (розуміння почуттів студентів);

- повага (прийняття студентів як конструктивних особистостей);

- щирість (відкритий прояв викладачем власних почуттів);

- конкретність комунікації (уникнення розпливчатих, узагальнених висловлювань, точний опис відчуттів і переживань) [4, с. 176].

Здатність бути щирим проявляється тоді, коли викладач дає єдину реакцію як на вербальному, так і невербальному рівні, як позитивну, так i негативну, причому остання не носить деструктивний характер; коли вербалізація відображає справжні почуття. Він має бути чесним у прояві щирості, по-перше, із самим собою, а по-друге, зі своїми учнями.

Коректність у спілкуванні досягається тим, що взаємини стають тіснішими, а мова спілкування менш ухильною, розпливчатою; розмова в аудиторії носить форму вільного діалогу, а не нагадує читання книги, під час якого один говорить, інші слухають.

Дослідницька функція викладача має три аспекти реалізації його дослідницької активності:

- перший аспект пов'язаний з тим, що до компетенції викладача входить самостійне виявлення тих чи інших навчальних проблем у студентів i вирішення конкретних практичних завдань у контексті природної педагогічної реальності. Викладач може зробити унікальний вклад, проводячи дослідження на рівні однієї групи, досліджуючи не лише ефективність того чи іншого прийому навчання або форми роботи, але й акцентуючи увагу на особистих стосунках між викладачем $\mathrm{i}$ студентом. Уміння здійснити аналіз розвитку взаємин, як і особистої динаміки кожного учасника у цьому процесі, знаходиться в основі дослідницької функції. Окрім того, принцип мотиваційної готовності аудиторії передбачає миттєве дослідження ситуації [7];

- другий аспект визначається використанням у процесі викладання психодіагностичних методів і процедур. Застосовуючи їх, викладач опиняється в ролі реального дослідника, що отримує доступ до специфічної інформації про розвиток іноземного студента як особистості;

- третій аспект дослідницької функції полягає у здійсненні викладачем у навчальному процесі розвиваючих «технологій» особистісного росту. 
Фасилітаторська функція виражається вже у самій якості взаємин «викладач-студент», побудованій на щирості викладача, безоцінному позитивному прийнятті ним особистості студента, емпатичному розумінні. Викладач не відгороджується від учнів маскою наставника, він спілкується 3 ними як жива людина, відкрито висловлює свої почуття $[3$, с. 8$]$. Емпатичне розуміння пов'язане зі здатністю викладача зрозуміти реакції студента-іноземця, усвідомити, що $є$ індивідуальний підхід до кожного учасника навчального процесу.

Експертна (консультативна) функція викладача виростає 3 потреби студента у викладачі, що володіє глибокими, системними знаннями, різносторонніми практичними навичками і вміннями. Такий викладач, захоплений тією чи іншою сферою пізнання чи практичної діяльності, здатний залучити студента до сфери власних інтересів [7, с. 8].

Очевидно, що всім переліченим вище вимогам може відповідати не кожен педагог. Такий педагог, окрім базової лінгвістично-педагогічної освіти, повинен також мати тенденцію до саморозвитку, творчого пошуку, розвинену здатність до рефлексії психологічної реальності, інтроспекції і особистісної імпровізації.

Виснов ки. Отже, підсумовуючи, зазначаємо, що у статті було запропоновано розробку методичної концепції навчання англомовної поезії, орієнтованої на комплексне формування в іноземних студентів-філологів навичок і вмінь роботи 3 поетичним твором на основі філологічного аналізу в умовах відсутності мовного середовища. Окрім того, у нашому дослідженні було запропоновано викладачеві іноземних мов той рівень професійної підготовки для роботи 3 іншомовною аудиторією, який відповідає вимогам сучасності, тобто знайти вирішення тих методичних завдань, які стоять перед сучасними педагогами англійської мови в іноземній аудиторії.

\section{ЛІТЕРАТУРА}

1. Блинова Т.А., Новиков А.В., Руднова Н.Н. Профессионально направленное обучение русскому языку иностранных граждан. Москва, 2010. С. 38-46.

2. Гальперин И.Р. Текст как объект лингвистического исследования. Изд. 4-е, стереотипное. Москва : КомКнига, 2006. 144c.

3. Джулай Г.Г. Особливості в організації процесу навчання іноземних студентів. Миколаїв : Вид-во ЧНУ, 2017. С. 9-12.

4. Довгодько Т. Особливості пропедевтичної підготовки студентів-іноземців та їх психолого-педагогічна адаптація у науковому середовищі вищих навчальних закладів. Харків : НТУ «ХП», 2008. $362 \mathrm{c.}$

5. Загоруйко И.Н. Эмотивно-оценочные клише в клиповой интернет-культуре. Вестник Удмуртского университета. Серия «История и филология», 2017. № 6. С. 856-862.

6. Лотман Ю.М. Анализ поэтического текста: Структура стиха. О поэтах и поэзии. Санкт-Петербург, 1996. C. $18-252$.

7. Палка О.В. Підготовка іноземних студентів вищих навчальних закладів технічного профілю України до вивчення професійної лексики. Київ, 2003. 18 с.

8. Рибаченко Л.І. Підготовка іноземних студентів у навчальних закладах України. Київ, 2000. 21 с.

9. Суворова П.Е. Конструирование культурных миров и языковая картина мира. Известия РГПУ им. А.И. Гериена, 2008. № 78. С. 143-154.

10. Januchowski-Hartley S.R. Poetry as a Creative Practice to Enhance Engagement and Learning in Conversation Science. BioScience. Volume 68. Issue 11, 1 November. 2018. Pp. 905-911.

11. Sule A. Kendrick Lamar, street poet of mental health. The Lancet, Volume 2. Issue 6. 2015. Pp. 496-498.

\section{REFERENCES}

1. Blinova, T.A., Novikov, A.V., Rudnova, N.N. (2010). Professionalno napravlennoe obucheniye russkomu yazyku inostrannuh grazhdan [Professionally directed training in Russian language for foreign citizens]. Moscow, p. 38-46.

2. Galperin, I.R. (2006). Tekst kak obyect lingvisticheskogo issledovaniya [Text as an object of linguistic research]. Moscow: KomKniga [in Russian].

3. Dzhulai, G.G. (2017). Osoblyvosti v organizatsii protsesy navchannya inozemnyh studentiv [Paculiarities in organization of studying process for international students]. Mykolaiv : Vyd-vo ChNU. P. 9-12.

4. Dovgodko, T. (2008). Osoblyvosti propedevtychnoi pidgotovky studentiv-inozemtsiv ta ih psyhologopedagogichna adaptatsia u naukovomy seredovushchi vyshchyh navchalnyh zakladiv [Paculiarities of propedeutic preparation of international students and their psychological and pedagogical adaptation to scientific environment at universities]. Kharkiv : NTU "HP", 362 p. 
5. Zagoruyko, I.N. (2017). Emotivno-otsenochnye klishe v klipovoi internet-kulture [Emotive and estimating cliché in clip internet culture]. Udmurtia Universuty Journal, History and Philology section, pp. 856 - 862.

6. Lotman, U.M. (1996). Analiz poeticheskogo teksta: Struktura stiha. O petah I poezii [Poetic text analysis: poem structure. About poets and poetry]. Sankt-Peterburg, pp. 18-252.

7. Palka, O.V. (2003). Pidgotovka inozemnyh studentiv vushchuh navchalnyh zakladiv tehnichnogo profilyu Ukrainu do vyvchennya profesiinoi leksyky [Preparation of international students at universities of Ukraine for learning professional lexis]. Kyiv, $18 \mathrm{p}$.

8. Rybachenko, L.I. (2000). Pidgotovka inozemnyh studentiv u navchalnyh zakladah Ukrainy [Preparation of international students at universities of Ukraine]. Kyiv, $21 \mathrm{p}$.

9. Suvorova, P.E. (2008.) Konstruirovanie kulturnyh mirov I yazykovaya kartina mira [Cultural worlds construction and language view of the world]. RGPU Journal, Vol. 78, pp. 143-154.

10. Januchowski-Hartley, S.R. (2018). Poetry as a Creative Practice to Enhance Engagement and Learning in Conversation Science. BioScience, Volume 68, Issue 11, pp. 905-911.

11. Sule, A. (2015). Kendrick Lamar, street poet of mental health. The Lancet, Volume 2, Issue 6, pp. 496-498. 